\title{
NEW RECORD FOR ASIA-PACIFIC OF Protoperidinium anomaloplaxum (Peridiniales, Dinophyceae) FROM VIETNAMESE WATERS
}

\author{
Phan Tan Luom ${ }^{1,2, *}$, Nguyen Ngoc Lam², Doan Nhu Hai ${ }^{2}$ \\ ${ }^{1}$ Graduate University of Science and Technology, VAST, Vietnam \\ ${ }^{2}$ Institute of Oceanography, VAST, Vietnam \\ Received 29 February 2020, accepted 10 June 2020
}

\begin{abstract}
Minusculum (Lebour) Balech is one of four subgenera of the genus Protoperidinium Bergh 1881. Only five species of this subgenus have been discovered worldwide, most of which are distributed in cold waters. In this study, Protoperidinium anomaloplaxum (Balech) Balech is reported from Vietnam and thus for the first time from Asia-Pacific waters. This species is illustrated with line drawing, light and scanning electron microscopic photographs and described details of the ornamentation of the thecal plates as well as its geographic distribution.
\end{abstract}

Keywords: Minusculum, Protoperidinium, Asia Pacific Ocean, distribution, new record, Vietnam.

Citation: Phan Tan Luom, Nguyen Ngoc Lam, Doan Nhu Hai, 2020. New record for Asia-Pacific of Protoperidinium anomaloplaxum (Peridiniales, Dinophyceae) from Vietnamese waters. Academia Journal of Biology, 42(2): 117-122. https://doi.org/10.15625/2615-9023/v42n2.14859.

*Corresponding author email: luom.dt@gmail.com

C2020 Vietnam Academy of Science and Technology (VAST) 


\section{INTRODUCTION}

Protoperidinium is the largest genus of dinoflagellates and occurs in all the oceans of the world (Balech, 1988). Balech (1974), when re-instating the genus Protoperidinium Bergh (1881), had transferred 231 marine species of Peridinium Ehrenberg (1830) to the Protoperidinium. He further subdivided the genus Protoperidinium into three subgenera based on the number of anterior intercalary plates and precingular plates: Minusculum (6 precingular and 3 intercalary plates); Archaeperidinium (7 precingular, 2 intercalary plates); and Protoperidinium (7 precingular, 3 intercalary plates). Faust (2006) later erected the subgenus Testeria Faust which has 7 precingular plates and 1 intercalary plate and no apical pore, for the Protoperidinium species.

The subgenus Minusculum comprises only five species: $P$. adulterum and $P$. defectum are endemic species to the Antarctic (Balech, 1974, 1988), P. bipes occurs in the Western Atlantic Ocean and Subantarctic waters (Balech, 1988), and P. anomaloplaxum found in Argentinean (Balech, 1988) and Brazilian waters (Jardim \& Cardoso, 2013). Recently, Protoperidinium smithii, a new species belonging to the subgenus Minusculum, has been described from the Ross Sea in Antarctica (Phan-Tan et al., 2018).

There were a number of studies on the genus Protoperidinium in Vietnamese waters. Species diversity of the subgenus Protoperidinium (sections Conica, Tabulata, and Oceanica) and subgenus Archaeperidinium has been studied by PhanTan et al. (2016a,b, 2017). The ecology of the genus Protoperidinium (Nguyen Luong Tung et al., 2017) was done for Con Dao Island.

In this paper, $P$. anomaloplaxum is reported for the first time from Vietnamese waters and it is also the first report of the species of the subgenus Minusculum from tropical waters. We present light and scanning electron microscopy of $P$. anomaloplaxum and describe details of the ornamentation of the thecal plates.

\section{MATERIALS AND METHODS}

\section{Sampling}

Phytoplankton samples were collected with vertical net hauls $(20 \mu \mathrm{m}$ mesh size and net diameter $30 \mathrm{~cm}$ ) from near the ocean floor to the surface in different locations of Vietnamese coastal waters. Samples were fixed with formaldehyde to a final concentration of approximately 5\% and then stored in $25 \mathrm{ml}$ dark glass bottles, reserved at the Institute of Oceanography, Nha Trang, Viet Nam.

\section{Analyses of samples}

The samples were examined under a Leica LDMB light microscope and by scanning electron microscopy (SEM). Observations of plate patterns were made with Calcofluor White M2R according to Fritz \& Triemer (1985). Digital camera Olympus DP71 was used for light and epifluorescence microphotography.

For SEM observation, cells of Protoperidinium were isolated from preserved samples and placed on a $5 \mu \mathrm{m}$ carbon membrane filter, rinsed with distilled water, dehydrated through an ascending ethanol series $(15,30,50,70,2 \mathrm{x} 96 \%$ and $2 \mathrm{x}$ absolute ethanol) and air dried. The filter was mounted onto an aluminum stub with carbon tape and finally sputter coated with gold. The stubs were examined on a Hitachi FM-SEM (model S4800 Field Emission-Scanning Electron Microscope) at the National Institute of Hygiene and Epidemiology (NIHE), Ha Noi, Vietnam.

\section{RESULTS AND DISCUSSION}

\section{Systematics}

Class Dinophyceae Pascher, 1914

Order Peridiniales Haeckel, 1894

Family Protoperidiniaceae Balech, 1988

Genus Protoperidinium Bergh, 1881

Subgenus Minusculum (Lebour, 1925) Balech, 1974

Protoperidinium

(Balech, 1964) Balech, 1974 
Members of this subgenus are characterized by their small size, strongly asymmetrical epitheca with four apical plates, three anterior intercalary plates, and only six precingular plates. The 6" plate is large and extends to the dorsal side of the cell and overlaps partially or totally the 5" plate (Balech, 1974, 1976, 1988).
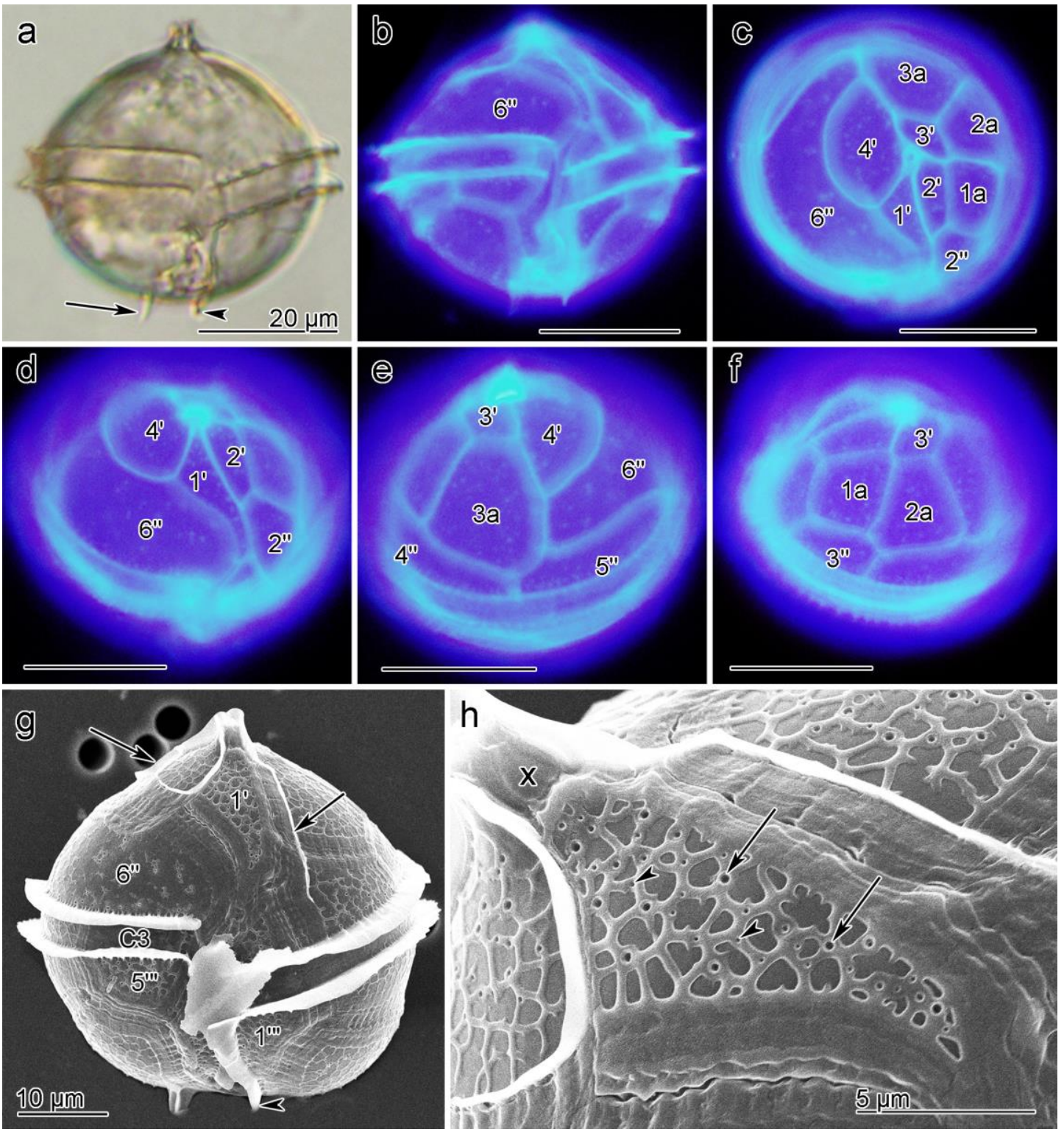

Figure 1. Protoperidinium anomaloplaxum: a (LM), b (Epi) \& g (SEM): a cell in ventral view showing the descending cingulum, plate pattern of thecal plates, right antapical wing spine (arrow), and left sulcal list (arrowhead), ornamentation of the thecal plates, narrow membrane along the sutures of apical plates (arrows), and wide striated intercalary bands; c (Epi): showing plate patterns of epitheca in apical view; $d$ (Epi): showing the epitheca plate patterns in ventral view; e \& f (Epi): showing the intercalary plates (1a, 2a, and 3a) in lateral view; h: (SEM): part of the theca with reticulation, pores of the varying size (arrows and arrowheads) and canal plate

(x). Epi: epifluorescence, LM: light microscope, and SEM: Scanning electron micrograph 


\section{Redescription of species}

\section{Protoperidinium}

anomaloplaxum

(Balech, 1964) Balech, 1974 (Figure 1a-1h, $2 a-2 c)$

Basionym: Peridinium anomaloplaxum Balech, 1964

Balech, 1964: p. 28, pl. III (34-46); Balech, 1974: p. 53; Balech, 1988: p. 82, pl. 22, Figs. 9, 11-13; Jardim \& Cardoso, 2013: 634, Fig. $1 \mathrm{H} \& \mathrm{I}$.

Description: The cells have napiform, wider than long (Figs. 1a, b, g, 2a, b) with a total length (including antapical spine) of 43$47 \mu \mathrm{m}, 38-40 \mu \mathrm{m}$ length, $40-45 \mu \mathrm{m}$ wide, and $30-32 \mu \mathrm{m}$ dorso-ventrally. The epitheca has short apical neck without an apical horn (Figs. 1a, 1b, 1g, 2a, 2b). There is a membrane along the sutures of apical plates (Figs. 1g, 2a, 2b). Plate l' has five sides (meta-type), long and narrow, very asymmetrical, with the right posterior side being strongly concave (Figs. 1b-1d, 1g, 1h, $\& 2 \mathrm{a}-2 \mathrm{c})$. There are six precingular plates, the plate 6" is exceptionally large, and extends onto the dorsal side of the cell (Figs. 1c-1e, $1 \mathrm{~g}, 2 \mathrm{a}-2 \mathrm{c})$. There are three anterior intercalary plates with the plate $2 \mathrm{a}$ of the penta-type. Due to the asymmetrical tabulation the intercalary plates lie on the left side of the cell (Figs. 1c, $2 c)$. The cingulum descends about one girdle width (Figs. 1a, 1b, 1g, \& 2a, 2b) and is bordered by wide lists supported by spines (Figs. 1e-1g, 2c). The cingular plate $\mathrm{C} 1$ very narrow, plate $\mathrm{C} 3$ is narrow (Figs $1 b, 2 b$ ) or wide (Figs 1g, 2a), and plate $\mathrm{C} 2$ is wide and surrounding more or less the whole cell (Figs $1 \mathrm{~b} \& 1 \mathrm{~g}, 2 \mathrm{~b}$ ). The hypotheca is hemispherical with only one antapical wingspine on the right and a left sulcal list extended looking as a spine (Figs. 1a, 1g, 2a, $2 b)$. The sulcus expands distally more towards the right than towards the left (Figs. 1b, 1g, \& $2 a, 2 b)$. The surface of the thecal plates is ornamented with reticulation and pores of the varying size (Figs. 1g, 1h). Our observations showed that the sutures with wide striated intercalary bands (Figs. $1 \mathrm{~g}-1 \mathrm{~h}$ ).
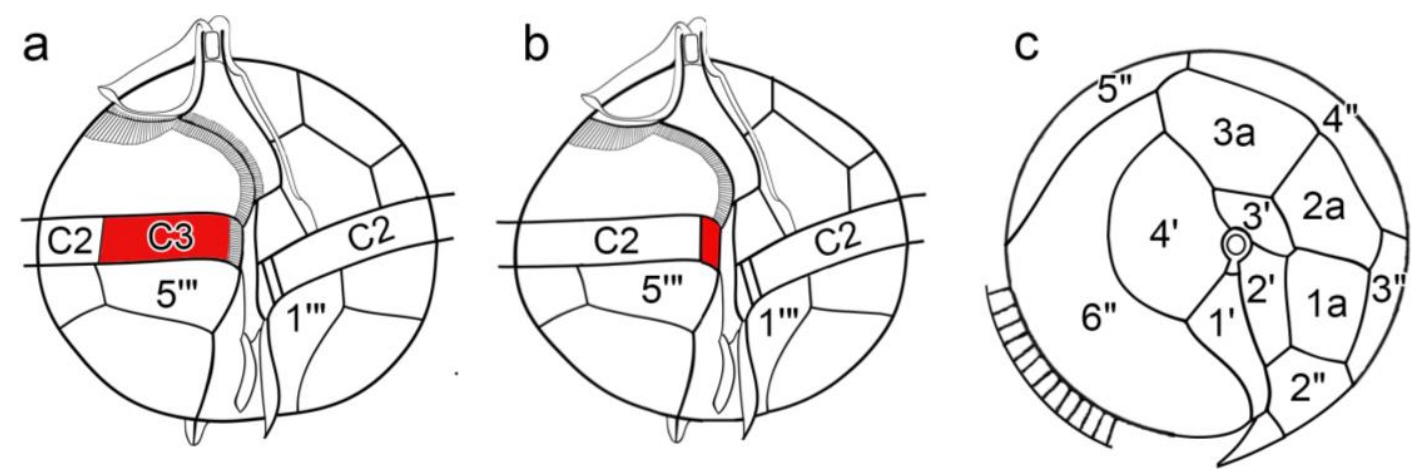

Figure 2. Protoperidinium anomaloplaxum: line drawing in ventral view showing wide cingular plate $\mathrm{C} 3$ (a), very narrow $\mathrm{C} 1$ and $\mathrm{C} 3$ plates (b), and the plate patterns of epitheca in apical view (c)

\section{Morphological notes}

The shape and tabulation of the Vietnamese material of Protoperidinium anomaloplaxum is identical to the type description, Peridinium anomaloplaxum Balech, 1964. The cingular plates C1 and C3 were very narrow (Figs. 1b \& 2b) (Balech, 1964, p. 29, pl. III, Figs. 34, 41; Balech 1988, pl. 22, Fig. 9). However, in a few cases, cells have wide cingular plate $\mathrm{C} 3$, nearly equal to the fifth postcingular (5")) plate (Figs. $1 \mathrm{~g} \&$ 2a). Protoperidinium anomaloplaxum is similar to $P$. adulterum with regard to the shape of the cell. However, the present species has a 2a-plate of the "penta-type", one antapical spine and a list lining the left side of the sulcus; whereas $P$. adulterum has a $2 \mathrm{a}$ - 
plate of the "quadra-type" and two antapical spines in addition to a sulcal list (Balech, 1974, 1988).

Yamaguchi et al. (2007) questioned the taxonomic status of the subgenus Minusculum as molecular data suggested that Protoperidinium (Minusculum) bipes should be included in the subgenus Protoperidinium. However, there are distinct morphological differences between the two subgenera (PhanTan et al., 2016b, 2017, 2018). The molecular data presented by Yamaguchi et al. (2007) also suggested that $P$. pentagonum which appears to morphologically belong to the Conica-group is related closer to the Divergentia-group. In our opinion, these discrepancies between the molecular data and the morphology of the species need to be clarified further before taxonomic conclusions can be drawn.

\section{Ecology and Distribution}

According to Balech (1988), $P$. anomaloplaxum has a particular distribution occurring between $37^{\circ} 39^{\prime} \mathrm{S}-38^{\circ} 42^{\prime} \mathrm{S}$ and $53^{\circ} 33^{\prime} \mathrm{W}-57^{\circ} 20^{\prime} \mathrm{W}$ in the waters off Mar del Plata, Argentina at temperatures from 14.6 to $18.0^{\circ} \mathrm{C}$, and salinities from 35.0 to $36.114 \mathrm{psu}$. Jardim \& Cardoso (2013) found $P$. anomaloplaxum in the Rio Grande do Sul, Brazil $\left(29^{\circ} 59^{\prime} 05^{\prime \prime}\right.$ S, 50 $50^{\circ} 08^{\prime} 01^{\prime \prime}$ W) at temperatures from 14.5 to $23^{\circ} \mathrm{C}$, salinities from 21.5 to $27.8 \mathrm{psu}$. In this study, $P$. anomaloplaxum has been found in Vietnam in the waters off Da Nang, Nha Trang Bay, and in the coastal waters of Con Dao Island at temperatures from 26 to $29^{\circ} \mathrm{C}$, and salinities from 33 to 34 psu.

\section{CONCLUSION}

$P$. anomaloplaxum of the subgenus Minusculum is reported for the first time in Vietnamese waters and also the first report in tropical waters. The species was previously only found in temperate waters of Argentina and Brazil and now in tropical waters showing its wide distribution and would be found in other waters. However, since it was only reported three times, this species may be considered as a rare species. Our finding is presently contributing to knowledge on the morphology and distribution of the species in the world.

Acknowledgements: This research is funded by the Graduate University of Science and Technology under grant number GUST.STS.ĐT2017-KHB01. Authors were also financed by the National Foundation for Science and Technology Development (NAFOSTED), Vietnam Ministry of Science and Technology via grant number: 106-NN.06-2017.305.

\section{REFERENCES}

Balech E., 1964. El plancton de Mar del Plata durante el período 1961-1962 (Buenos Aires, Argentina). Boletín del Instituto de Biología Marina, 4: 1-49.

Balech E., 1974. El género Protoperidinium Bergh, 1881("Peridinium", Ehrenberg, 1831, partim). Revista del Museo Argentino de Ciencias Naturales "Bernardino Rivadavia" Instituto Nacional de Investigación de las Ciencias Naturales, Hidrobiologia, 4(1): 1-79.

Balech E., 1976. Clave ilustrada de dinoflagelados antárticos. Publ. Inst. Antártico Argentino, 11: 1-99.

Balech E., 1988. Los dinoflagelados del Atlantico Sudoccidental. Ministerio de Agricultura Pesca y Alimentacion, Inst. Esp. Oceanogr. Sp. Pub. 1, Madrid, 310 pp.

Faust M. A., 2006. Creation of the subgenus Testeria Faust subgen. nov. Protoperidinium Bergh from the SW Atlantic Ocean: Protoperidinium novella sp. nov. and Protoperidinium conicinna sp. nov. Dinophyceae. Phycologia, 45: 1-9.

Fritz L., Triemer R. E., 1985. A rapid simple technique utilizing Calcofluor White M2R for the visualization of dinoflagellate thecal plates. Journal of Phycology, 21: 662-664.

Jardim P. F. G., de Souza Cardoso L., 2013. New distribution records of Dinophyta in Brazilian waters. CheckList, 9 (3): 631-639. 
Phan Tan Luom, Nguyen Ngoc Lam, Doan Nhu Hai, 2016a. Taxonomy of dinoflagellates, the genus Protoperidium (Archaeperidinium), in coastal waters of Vietnam. Journal of Biology, 38(1): 39-52. https://doi.org/10.15625/08667160/v38n1.7596 (in Vietnamese with English summary).

Phan-Tan L., Nguyen-Ngoc L., Doan-Nhu H., 2016b. Species diversity of sections Conica and Tabulata in the genus Protoperidinium (Dinophyceae) from tropical waters of the South China Sea. Nova Hedwigia, 103(3-4): 515-545. http://dx.doi.org/10.1127/nova_hedwigia/ 2016/0369. ISSN 0029-5035.

Phan-Tan L., Nguyen-Ngoc L., Doan-Nhu H., Raine R. and Larsen J., 2017. Species diversity of the dinoflagellate genus Protoperidinium section Oceanica (Dinophyceae, Peridiniales) in Vietnamese waters, with description of a new species-P. larsenii sp. nov. Nordic Journal of Botany, 35: 129-146. https://doi.org/10.1111/njb.01230. ISSN 1756-1051.
Phan-Tan L., Nguyen-Ngoc L., Smith W. O., Jr. \& Doan-Nhu H., 2018. A new dinoflagellate species, Protoperidinium smithii H. Doan-Nhu, L. Phan-Tan et L. Nguyen-Ngoc sp. nov., and an emended description of Protoperidinium defectum (Balech 1965) Balech 1974 from the Ross Sea, Antarctica. Polar Biology, 41: 983-992. https://doi.org/10.1007/s00300018-2262-0.

Nguyen Luong Tung, Phan Tan Luom, Nguyen Thi Tuong Vi, 2017. Species composition and abundance of genus Protoperidinium (dinoflagellate) in Con Dao coastal waters, Ba Ria-Vung Tau. Journal of Science and Technology of the University of Da Nang. ISSN 1859-1531, 01(110): 131-135 (in Vietnamese with English summary).

Yamaguchi A., Kawamura H., Horiguchi T., 2007. The phylogenetic position of an unusual Protoperidinium species, $P$. bipes (Peridiniales, Dinophyceae), based on small and large subunit ribosomal RNA gene sequences. Phycology, 46(3): 270-276. DOI: 10.2216/06-82.1. 